\title{
One Slope Model: Efforts to Optimize Wifi Networks in the Office of communication and informatics (Diskominfo) in Palembang
}

\author{
Winda Wulandari ${ }^{1}$, Ari Muzakir ${ }^{2 *}$ \\ 1,2Informatics Department, Universitas Bina Darma, Palembang, Indonesia \\ Email: 1windawulandari519@gmail.com, 2arimuzakir@binadarma.ac.id
}

\begin{abstract}
Information technology in the field of transmission that is currently developing, one of which is Wi-Fi. Wi-Fi devices provide user convenience in carrying out their activities. The quality of Wi-Fi network performance can be known by the reception of the signal received by the user. If the placement of an access point (AP) is done correctly, the network will be optimized. There are several propagation models in the room that can be used as a guideline in determining the placement of the AP, one slope model is a way to measure the average level of a building and only depends on the distance of the transmitter and receiver. This research was conducted in order to overcome the problem of Wi-Fi network area coverage at the Office of Communication and Information of the City of Palembang. This study conducted an experiment to change the layout of AP's placement, measure and calculate data in priority with the one slope model. The results of measurements and calculations carried out analysis and comparison in order to determine the results of experiments conducted. The results of this study indicate that an attempt to change the AP layout with one slope model can overcome existing problems and get better Wi-Fi coverage area performance. In the calculation with the one slope model of the 2-trial access point placement results in a decrease and an increase in signal. The signal reduction occurred in experiment 1, whereas in experiment 2 (design 2) the signal increased by $1.46 \mathrm{dBm}$.
\end{abstract}

Keywords: optimizations wireless network, indoor propagation model, one slope model, experimental network optimization, model pathloss

\section{INTRODUCTION}

Saat ini sudah semakin banyak pusat pembelanjaan, airport, rumah sakit, dan lokasi lain yang menyediakan layanan wireless network yang disebut area hotspot. Sehingga pengguna dapat dengan mudah melakukan akses internet menggunakan smartphone, laptop, tablet, dan perangkat mobile lainnya. Frekuensi yang digunakan wireless network adalah $2.4 \mathrm{GHz}$ dan $5.8 \mathrm{GHz}$, penggunaan infrared dan laser 
umumnya hanya terbatas untuk jenis jaringan yang hanya melibatkan dua buah titik saja (disebut point to point atau p2p) [1][2].

Kualitas suatu jaringan wieless dapat diketahui dari penerimaan sinyal yang diterima oleh pengguna. Apabila penempatan access point dalam suatu gedung dilakukan secara tepat maka kinerja jaringan wireless akan lebih optimal. Terdapat beberapa model propagasi dalam ruangan yang dapat dijadikan pedoman dalam penempatan AP (Access Point), diantaranya yaitu One Slope Model adalah cara paling mudah untuk mengukur level sinyal rata-rata pada suatu bangunan tanpa harus mengetahui layout suatu bangunan secara detail karena hanya bergantung pada jarak antara pemancar dan penerima [3] [4][5].

Dinas Komunikasi dan Informatika (Diskominfo) Kota Palembang adalah salah satu Dinas Teknis dilingkungan Pemerintah kota Palembang yang menyelenggarakan kewenangan urusan pemerintahan Komunikasi dan Informatika pada Kota Palembang Secara legal formal, Diskominfo Palembang dibentuk berdasarkan peraturan walikota (purwako) No 58 tahun 2016 tentang kedudukan, susunan organisasi, tugas dan fungsi serta tata kerja dinas komunikasi dan informatika palembang. Dinas Komunikasi dan Informatika Kota Palembang terdiri dari 2 lantai yaitu pada lantai 1 terdapat Ruang Server, Control, Egov, Call Center 112, Media Center, Layanan Informasi Publik, dan Ruang Kabid POPIP sedangkan pada lantai 2 terdapat Ruang Keuangan, Sekdin, Kabag Pengaduan dan Informasi Publi, Kadin, Ruang Rapat, Kabag Pengelola Opini dan Pelayanan Informasi Publi, Bendahara, dan Ruangan Teknologi Informasi dan Persandian. Mempunyai alat 4 access point (2 lantai 1 dan 2 lantai 2), Mikrotik, Hub. Jaringan Komputer yang digunakan Dinas Komunikasi dan Informatika Kota Palembang adalah jaringan WLAN (Wireless Local Area Network).

Pada Dinas komunikasi dan Informatika Kota Palembang memiliki jaringan $W i$-Fi yang berfungsi sebagai penyediaan bagi pegawai yang akan digunakan untuk memperoleh informasi dan pengolahan data. Namun kualitas jaringan yang tersedia masih kurang optimal karena ada beberapa area yang tidak terliputi dengan baik oleh jaringan $W i$-Fi.

\section{METHODS}

\subsection{Metode Experimen}

Metode eksperimen adalah metode penelitian yang digunakan untuk mengetahui pengaruh variable independen (treatment/pelakuan/tindakan) terhadap variable dependen (hasil) dalam kondisi yang terkendalikan. Kondisi dikendalikan agar tidak ada variable lain (selain variabel tindakan) yang dapat 
mempengaruhi variabel dependen. Agar kondisi dapat dikendalikan, maka dalama penelitian eksprimen menggunakan kelompok kontrol [6][7].

Terdapat beberapa bentuk desain experimen yang dapat digunakan dalam penelitian untuk penelitian kebijakan, yaitu: Pre-Experimental Design, TrueExperimental Design, Factorial Design, dan Quasi Experimental Design. Dalam penelitian ini penulis menggunakan Pre-Experimental Design. Pre-ExperimentalDesign mempunyai tiga bentuk desain yaitu: One Shot Case Study, One GroubPretest-Postest, dan Intac Groub Comparison. Dari ketiga bentuk tersebut peneliti menggunakan One Groub Pretest-Postest. Dimana pada desain ini terdapat pretest (data pengukuran sebelum diberi perlakuan). Dengan demikian hasil perlakuan dapat diketahui lebih akurat, karena dapat membandingkan dengan keadaan variable sebelum diberi perlakuan dan sesudah diberi perlakuan [8][9].

Adapun langkah-langkah pengujian tindakan untuk perbaikan kinerja yaitu:
a. Perencanaan (Plan)
b. Pelaksanaan Tindakan (Act)
c. Pengamatan (Observe)
d. Refleksi (reflektion).

\subsection{Metode Pengumpulan Data}

Metode Pengumpulan Data yang digunakan dalam penelitian ini adalah [7]:

1. Kepustakaan

Mengumpulkan data dengan cara mencari dan mempelajari data-data dari buku-buku ataupun dari referensi lain yang berhubungan dengan penulisan laporan penelitian ini.

2. Observasi

Observasi sebagai teknik pengumpulan data memepunyai ciri yang spesifik, bila dibandingkan dengan teknik yang lain, yaitu wawancara dan kuisioner. Observasi tidak terbatas pada orang, tetapi juga obyek-obyek alam yang lain.

3. Wawancara

Digunakan sebagai teknik pengumpulan data apabila peneliti ingin melakukan studi pendahuluan untuk menemukan permasalahan yang harus diteliti, dan juga apabila peneliti ingin mengetahui hal-hal dari responden yang lebih mendalam dan jumlah respondennya sedikit/kecil.

4. Dokumentasi

Dokumentasi adalah cara mengumpulkan data melalui peninggalan tertulis, seperti arsip-arsip dan buku-buku tentang pendapat, teori yang berhubungan dengan masalah penelitian. 


\subsection{Metode Optimasi Converage Area}

Terdapat beberapa model propagasi dalam ruangan yang dapat dijadikan pedoman dalam penempatan AP (Access Point), diantaranya yaitu One Slope Model adalah cara paling mudah untuk mengukur level sinyal rata-rata pada suatu bangunan tanpa harus mengetahui layout suatu bangunan secara detail karena hanya bergantung pada jarak antara pemancar dan penerima [4][5].

Converage area merupakan area cakupan yang dapat dijangkau oleh sinyal wi-fi. Jika seorang semakin jauh dari coverage area maka sinyal yang didapat akan semakins sedikit. Coverage area juga dapat menentukan signals strength. Dengan melihat coverage area dari sebuah access point maka akan dapat mentukan tata letak penempatan AP yang tepat sehingga mengurangi terjadinya blank spot area [10].

Decibles dalam kaitannya dengan miliwatt (biasanya -30 sampai -100). Hal pertama yang harus dipahami tentang $\mathrm{dBm}$ adalah kami bekerja dalam hal negatif. -30 adalah sinyal yang lebih tinggi dari -80 , karena -80 adalah angka yang jauh lebih rendah. Adapun angka-angka kekuatan sinyal yang diinginkan akan bervariasi, berdasarkan persyaratan untuk jaringan.

Tabel 1. Angka-Angka Kekuatan Sinyal [3]

\begin{tabular}{|c|c|c|c|c|}
\hline No & $\begin{array}{c}\text { Kekuatan } \\
\text { Sinyal }\end{array}$ & $\begin{array}{c}\text { Keteranga } \\
\mathbf{n}\end{array}$ & Kualitas yang diharapkan & $\begin{array}{c}\text { Dibutuhkan } \\
\text { untuk }\end{array}$ \\
\hline 1 & $-30 \mathrm{dBm}$ & Luar biasa & $\begin{array}{l}\text { Kekuatan sinyal maksimum dicapai. } \\
\text { Klien hanya bisa beberapa meter dari } \\
\text { AP untuk mencapai ini. Tidak khas } \\
\text { atau diinginkan di dunia nyata }\end{array}$ & $\mathrm{T} / \mathrm{A}$ \\
\hline 2 & $-67 \mathrm{dBm}$ & $\begin{array}{l}\text { Sangat } \\
\text { bagus }\end{array}$ & $\begin{array}{l}\text { Kekuatan sinyal minimum untuk } \\
\text { aplikasi yang membutuhkan } \\
\text { pengiriman paket data yang sangat } \\
\text { handal dan tepat waktu }\end{array}$ & $\begin{array}{l}\text { VoIP/VoWiFi, } \\
\text { streaming video }\end{array}$ \\
\hline 3 & $-70 \mathrm{dBm}$ & Baik & $\begin{array}{l}\text { Kekuatan sinyal minimum untuk } \\
\text { pengiriman paket yang dapat } \\
\text { diandalkan }\end{array}$ & Email, web \\
\hline 4 & $-80 \mathrm{dBm}$ & Tidak baik & $\begin{array}{l}\text { Kakuatan sinyal minimum untuk } \\
\text { konektivitas dasar. Pengiriman paket } \\
\text { mungkin tidak dapat diandalkan }\end{array}$ & $\mathrm{T} / \mathrm{A}$ \\
\hline 5 & $-90 \mathrm{dBm}$ & $\begin{array}{l}\text { Tidak bisa } \\
\text { dipakai }\end{array}$ & $\begin{array}{l}\text { Mendekati atau tenggelam di lantai } \\
\text { kebisingan. Fungsi apa pun sangat } \\
\text { tidak mungkin }\end{array}$ & $\mathrm{T} / \mathrm{A}$ \\
\hline
\end{tabular}




\subsection{Model Propagasi Dalam Ruangan}

Propagasi dalam ruangan suatu gelombang elektromaknetik merupakan bagian terpenting dari suatu sistem wireless LAN, codless phone, dan sistem wireless yang digunakan didalam suatu gedung. Karekteristik propagasi dalam ruangan akan sering terdapat multipath dan kemungkinan terdapatnya line-of-sing path, selain itu cakupan daerah kerjanya lebih kecil, yaitu sekitar 100 meter atau bahkan kurang dari 100 meter. Tata ruang sautu bangunan tersebut akan sangat mempengaruhi kualitas sinyal yang diterima pada sisi receiver. Selain itu keadaan sautu gedung dapat berubah secara drastis pada waktu yang singkat karena adanya multipath, pergerakan orang-orang yang beraktifitas dalam bangunan tersebut atau adanya suatu dinding pemisah, furniture, dan peralatan-peralatan lain dapat membuat loss yang signifikan. Terdapat beberapa model propagasi dalam ruangan yang dapat dijadikan pedoman dalam penempatan AP (Access Point), diantaranya yaitu one slope model adalah cara paling mudah untuk mengukur level sinyal rata-rata pada suatu bangunan tanpa harus mengetahui layout suatu bangunan secara detail karena hanya bergantung pada jarak antara pemancar dan penerima [4].

Untuk merancang suatu jaringan wireless LAN, karakteristik-karakteristik propagasi indoor diatas harus diperhatikan. Pada indoor wireless communication (IWC) seperti jaringan WLAN, dapat saja Athena penerima dan pemancar berada dalam suatu raungan yang saling membahayangi (shadowed) ruangan akan memiliki efek yang nyata pada statistik sinyal yang diterima pada penerima. Untuk mempermudah tentang propagasi radio dalam suatu ruangan, maka ada beberapa metode untuk mendekatinya seperti beberapa pemodelan secara empiris. Pemodelan secaa empiris merupakan pemodelan yang sangat sederhana terutama berdasarkan pada data experimental.

One Slope Model adalah cari mudah untuk mengukur level sinyal rata-rata pada suatu bangunan tanpa harus mengetahui layout suatu bangunan secara detail karena hanya bergantung pada jarak antara pemancar dan penerima. Titik perhitungan akan dilakukan berdasarkan jarak titik pengukuran. Jarak (m) akan dimasukkan kedalam parameter one slope model dan mecari nilai $L O$, n, environment sesuai dengan Frequency yang digunakan.Adapun cara perhitungan One Slope Model adalah dengan metode Pathloss. Pathloss adalah suatu metode yang digunakan untuk mengukur suatu loss yang disebabkan oleh cuaca, kontur tanah dan lain-lain, agar tidak menggangu pemancaran antar 2 buah antena yang saling berhubungan. Nilai pathloss menunjukkan level sinyal yang melemah (mengalami attenuation) yang disebabkan oleh propagasi free space seperti refleksi, difraksi, dan scattering. Path loss sangat penting dalam perhitungan Link Budget, ukuran cell, ataupun perencanaan frekuensi. faktor-faktor yang mempengaruhi nilai level daya dan pathloss adalah jarak pengukuran antara Tx dan $\mathrm{Rx}$, tinggi antena (Tx dan Rx), serta jenis area pengukuran [11].

Link Budget untuk mengetahui seberapa besar daya yang diterima di sisi penerima, cara yang paling baik adalah membuat link budged. Persamaan link budged sebagai berikut. Link budget merupakan sebuah cara untuk menghitung mengenai semua parameter dalam transmisi sinyal, mulai dari gain dan losses dari Tx sampai Rx melalui media transmisi. Link merupakan parameter dalam merencanakan suatu jaringan yang 
menggunakan media transmisi berbagai macam. Link budget ini dihitung berdasarkan jarak antara transmitter $(\mathrm{Tx})$ dan receiver $(\mathrm{Rx})$. Link budget juga dihitung karena adanya penghalang antara Tx dan Rx misal gedung atau pepohonan. Link budget juga dihitung dengan melihat spesifikasi yang ada pada antenna.

Untuk parameter pengukuran dapat dilihat pada tabel 1. Model ini memiliki persamaan sebagai berikut.

$L(d)=L 0+10 n \log (d)(1)$.

Keterangan:

LO = Rugi-rugi jalur dari TX ke RX terhadap referensi jarak Ro pada propagasi free space (dalam dB), Ro adalah referensi jarak Tx ke Rx yaitu 1 (satu) meter

$n$ = power decay factor (exponen rugi-rugi jalur)

$d \quad=$ jarak dari pemancar ke penerima.

Parameter one slope model ditunjukan dalam tabel dibawah ini.

Tabel 2. Parameter One Slope Model

\begin{tabular}{cccl}
\hline $\mathbf{F}(\mathbf{G H z})$ & $\mathbf{L 0}(\mathbf{d B})$ & $\mathbf{N}$ & \multicolumn{1}{c}{ Keterangan } \\
\hline 1.8 & 33.3 & 4.0 & Kantor \\
1.8 & 37.5 & 2.0 & Ruangan Terbuka \\
1.8 & 39.2 & 1.4 & Koridor \\
1.9 & 38.0 & 3.5 & Bangunan Kantor \\
1.9 & 38.0 & 2.0 & Lorong \\
1.9 & 38.0 & 1.3 & Koridor \\
2.45 & 40.2 & 4.2 & Bangunan Kantor \\
2.45 & 40.2 & 1.2 & Koridor \\
2.45 & 40.0 & 3.5 & Bangunan Kantor \\
2.5 & 40.0 & 3.7 & Bangunan Kantor \\
5.0 & 46.4 & 3.5 & Bangunan Kantor \\
5.25 & 46.8 & 4.6 & Bangunan Kantor \\
\hline
\end{tabular}

Untuk mengetahui seberapa besar daya yang diterima di sisi penerima, cara yang paling baik adalah membuat link budged. Persamaan link budged sebagai berikut.

$P_{R}(d B m) P_{T}(d B m) G_{T}(d B m) G_{R}(d B m) L_{L P}(d B m)$.

Keterangan:

$P_{\mathrm{R}}=$ Daya terima $(\mathrm{dBm})$

$P_{T}=$ Daya pancar $(\mathrm{dBm})$

$G_{T}=$ Gain antena pemancar $(\mathrm{dBm})$

$G_{\mathrm{R}}=$ Gain antena penerima $(\mathrm{dBm})$.

$\mathrm{L}_{\mathrm{LP}}=$ Hasil pathloos dari perhitungan dengan one slope model. 


p-ISSN: 2656-5935 http://journal-isi.org/index.php/isi e-ISSN: 2656-4882

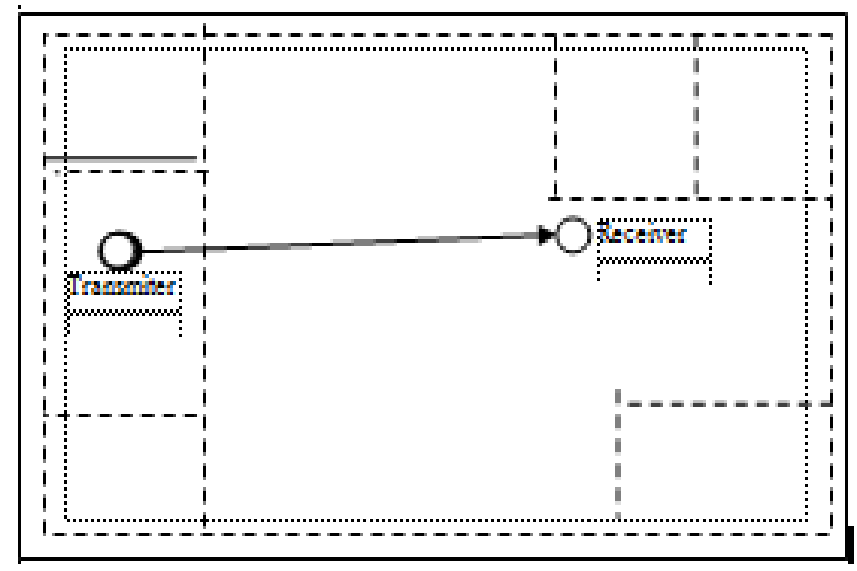

Gambar 1. Bentuk Penerapan One Slope Model

\section{RESULTS AND DISCUSSION}

\subsection{Hasil Tindakan}

Untuk mengetahui hasil tindakan yang dilakukan maka akan dilakukan perbandingan hasil pengukuran dan perhitungan. Fungsi perbandingan adalah untuk menentukan dimana penempatan access point paling ideal (menentukan desain yang digunakan). Data yang akan dilakukan perbandingan yaitu rata-rata kekuatan sinyal yang didapat.

\subsection{Hasil Pengukuran dan Perbandingan}

Dalam melakukan percobaan, pengukuran sinyal dalam metode optimasi ini yaitu dilakukan berdasarkan model propagasi dalam ruangan (one slope mode) access point akan diukur menggunakan model regresi (gambar 2), yaitu memilih lokasi disekitar access point yang berjarak d. Pengukuran akan dilakukan disetiap lantai gedung dan pada titik meja kerja karyawan dan titik gedung (ruanganruangan) yang memungkinkan pengaksesan wi-fi dilakukan.

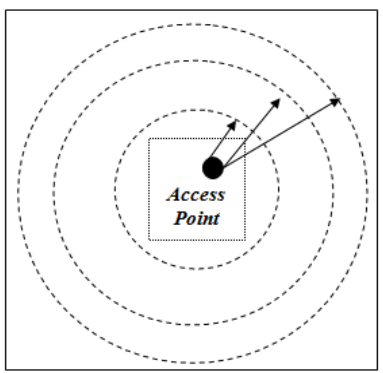

Gambar 2. Model Regresi 
Hasil pengukuran menunjukan pemindahan penempatan AP mempengaruhi kekuatan sinyal yang didapatkan di sisi penerima (receiver). Ratarata sinyal yang didapatkan dapat dilihat pada table dibawah ini.

Tabel 3. Hasil Rata-rata Pengukuran Sinyal.

\begin{tabular}{cccc}
\hline Lantai & Data awal & Desain 1 & \multicolumn{1}{c}{ Desain 2 } \\
\hline 1 & $-69 \mathrm{dBm}$ & $-52 \mathrm{dBm}$ & $-80 \mathrm{dBm}$ \\
2 & $-74 \mathrm{dBm}$ & $-76 \mathrm{dBm}$ & $-54 \mathrm{dBm}$ \\
\multirow{2}{*}{ Rata-rata } & $-71 \mathrm{dBm}$ & $-64 \mathrm{dBm}$ & $-67 \mathrm{dBm}$ \\
\hline
\end{tabular}

Rata-rata sinyal terbesar yang didapat dari hasil pengukuran yaitu pada desain 1 sebesar $-64 \mathrm{dBm}$. Selisih penerimaan sinyal data kontorl/awal dengan desain 1 yaitu $-7 \mathrm{dBm}$ dan desain 2 selisih $-4 \mathrm{dBm}$.

\subsection{Hasil Perhitungan Dengan One Slope Model dan Perbandingan}

Pada perhitungan one slope model yang hanya menghitung kekuatan sinya berdasarkan jarak maka hasil yang didapatkan dari percobaan pemindahan AP mengalami peningkatan dan juga penurunan sinyal. Data rata-rata perhitungan sinyal dapat dilihat sebagai berikut.

Tabel 4. Hasil Rata-Rata Perhitungan Sinyal dengan one slope model.

\begin{tabular}{cccc}
\hline Lantai & Data awal & Desain 1 & Desain 2 \\
\hline 1 & $-37.17 \mathrm{dBm}$ & $-30.80 \mathrm{dBm}$ & $-39.91 \mathrm{dBm}$ \\
2 & $-31.47 \mathrm{dBm}$ & $-41.32 \mathrm{dBm}$ & $-26.46 \mathrm{dBm}$ \\
Rata-rata & $-34.64 \mathrm{dBm}$ & $-36.06 \mathrm{dBm}$ & $-33.18 \mathrm{dBm}$ \\
\hline
\end{tabular}

Perhitungan one slope model menunjukan hasil bahwa data rata-rata sinyal terbesar yaitu pada desain 2. Dari perhitungan one slope model sinyal yang mengalami peningkatan yaitu di desain 2 (Selisih penerimaan sinyal data kontrol dengan desain 2 sebesar $-1.46 \mathrm{dBm}$ ), dan untuk desain yang mengalami penurunan sinyal yaitu pada desain 1 (sebesar $-1.42 \mathrm{dBm}$ ).

\subsection{Hasil Refleksi}

Berdasarkan hasil pengukuran sinyal yang telah dibahas sebelumnya, bahwa percobaan penempatan access point pada desain 1 dan 2 menunjukan ratarata sinyal yang didapat mengalami peningkatan. Namun terdapat beberapa 
desain yang dimana dititik pengukuran pada lantai mengalami peurunan sinyal. Dari hasil analisis data desain yang telah dijabarkan, penurunan sinyal yang terjadi yaitu pada desain 2. Dan pada desain 1 titik pengukuran mengalami rata-rata sinyal yang baik.

Hasil perhitungan one slope model menunjukan nilai rata-rata sinyal yang didapat mengalami penurunan dan juga peningkatan. Peningkatan nilai sinyal yaitu berada pada desain 2 Karena perhitungan one slope model hanya menghitung berdasarkan jarak (antara pemancar dan penerima) dan nilai dipengarui oleh environment (lingkungan yang ada pada gedung) pada desain 1 nilai sinyal mengalami penurunan.

\section{CONCLUSION}

1. Dari hasil percobaan penempatan access point, maka dapat mengetahui dimana penempatan access point yang baik.

2. Pada perhitungan dengan one slope model dari 2 percobaan penempatan access point didapatkan hasil penurunan dan peningkatan sinyal. Penurunan sinyal terjadi pada percobaan 1, sedangkan pada percobaan ke 2 (desain 2) sinyal meningkat sebesar $1.46 \mathrm{dBm}$.

3. Perbedaan hasil pengukuran dan perhitungan disebabkan karena perhitungan dengan one slope model hanya menghitung berdasarkan jarak. Perhitungan dengan one slope model cukup berpengaruh karena jarak dapat mempengaruhi kinerja.

\section{REFERENCES}

[1] Cisco Systems, "Cisco CCNA Security," CCNA Security, 2016.

[2] A. Muzakir and M. Ulfa, "ANALISIS KINERJA PACKET FILTERING BERBASIS MIKROTIK ROUTERBOARD PADA SISTEM KEAMANAN JARINGAN," Simetris J. Tek. Mesin, Elektro dan Ilmu Komput., vol. 10, no. 1, pp. 15-20, 2019.

[3] S. Parji, F. Fatoni, and R. Andryani, "Optimasi Jaringan Wireless Lan Dengan One Slope Model (Studi Kasus: PT Adovelin Raharja Shipping)," in Bina Darma Conference on Computer Science (BDCCS), 2019, vol. 1, no. 1, pp. 33-40.

[4] D. Angela, "Optimasi Jaringan Wireless Lan (Studi Kasus Di Kampus Ithb Bandung)," J. Telemat., vol. 6, no. 1, 2015.

[5] F. S. Mukti and D. A. Sulistyo, "Analisis Penempatan Access Point Pada Jaringan Wireless LAN STMIK Asia Malang Menggunakan One Slope Model," J. Ilm. Teknol. Inf. Asia, vol. 13, no. 1, pp. 13-22, 2018.

[6] E. Nahartyo, "Desain dan Implementasi Riset Eksperimen," Work. Metod. Ris. Eksp., 2016. 
[7] P. D. Sugiyono, metode penelitian kuantitatif, kualitatif,dan R\&D. 2016.

[8] I. Prasetyo, "Teknik Analisis Data Dalam Research And Development." Jurusan PLS FIP Universitas Negeri Yogyakarta, 2012.

[9] A. Muzakir and C. D. Kusmindari, "Design of Push-Up Detector Applications Using Quality Function Development and Anthropometry For Movement Error Detection," Sci. J. Informatics, vol. 5, no. 2, pp. 248257, 2018.

[10] L. P. A. S. Aryaningrum, R. P. Astuti, and A. Fahmi, "Perancangan Dan Analisis Coverage Area Jaringan Wifi Pada Gerbong Kereta Api Penumpang Eksekutif Jakarta-bandung (design And Analisys Of Coverage Area Wifi Network On Carriage Executive Railway Passenger Depart Jakarta-bandung)," eProceedings Eng., vol. 3, no. 3, 2016.

[11] M. A. AMANAF, "Analisis Optimasi Perencanaan Ulang Access Point Wifi Dengan Model Pathloss COST 231 Multi Wall dan Metode Offered Bit Quantity (OBQ) Studi Kasus Gedung Telematika ITTP,” J. Telecommun. Electron. Control Eng., 2019. 